\title{
THE EMERGENCE AND DEVELOPMENT OF THE SOCIOLOGY OF LAW IN HUNGARY: A HISTORICAL ASPECT
}

\author{
Ivan PERESH* \\ Taras DATSO** \\ Myroslava ZAN ${ }^{* * *}$ \\ Maryna KOHUT ${ }^{* * * * *}$
}

\begin{abstract}
The scientific article is devoted to the discovery and analysis of the historical preconditions for the occurrence and formation of the Hungarian School of Sociology of Law. It explores the basic sociological and legaltheories and concepts of Hungarian scholars, their contribution to the historical development of the European Sociological jurisprudence.
\end{abstract}

Keywords: Sociology, Sociology of Law, Hungarian Republic, history of Sociology of the Law of Hungary, sociological and legal concepts, A. Pulski, D. Pickler, B. Shomlo, B. Horvat, K. Kulchar, V. Peska.

Hungarian sociological and legal ideology has always been characterized by a significant political element, the influence of the positivism of Western sociology and the historicity of legal thinking. This is due tothe fact that for a long time the legal and sociological science of Hungary developed under the conditions of the agrarian semi-colony of the Austro-Hungarian monarchy, essentially being a predominantly a peasant country without a significant layer of the bourgeoisie. Therefore, the first sociological and legal (socio-legal) research was painted politically-negative response to discrimination against national minorities living in the territory of a huge monarchy.

The founder of the sociological jurisprudence of Hungary is considered to be the eminent philosopher-lawyer, professor of Budapest University Ahosht Pulski (1846-1901). It was he in the second half of the nineteenth century introduced the first sociological elements in

\footnotetext{
* $\mathrm{PhD}$, Associate Professor of the Department of Theory and History of State and Law, Uzhgorod National University, Ukraine.

** Senior Lecturer of the Department of Classical and Romanian Philology, Uzhgorod National University, Ukraine.

*** Senior Lecturer of the Department of Theory and History of State and Law, Uzhgorod National University, Ukraine.

**** Senior Lecturer of the Department of Theory and History of State and Law, Uzhgorod National University, Ukraine.
} 
jurisprudence. The scientist believed that the law arose as a result of the need to solve social problems and ensure the stability of social progress. The problems of society and the state should be solved gradually and in stages, in order to minimize the negative consequences of rapid socio-political change. However, his concept of "gradual social development" was negatively perceived by the Hungarian bourgeoisie, which wanted immediate changes in the political and legal system.

The concept, launched by Ahosht Pulski, found a continuation in the works of Dyula Pickler (1864-1937). In scientist researches traced the significant influence of Spencer's positions on the philosophy of law.He saw the idea of freedom of law in the field of private law, where the rules of law should set priorities and serve social progress.For the first time in Hungary, Pickler attempted to substantiate the needto distinguish the sociology of law as a new scientific direction.

The works of Professor of the University of Kolozhvary and the Law Academy of Nodwarodi Bodoga Shomlo (1873-1920) are imbued with the actual provisions of the psychologization of the doctrines on the state and law. The scientist paid considerable attention not only to the influence of historical development on the formation of law, but also the psychological properties of the individual and society and their influence on law.

On the basis of the works of the aforementioned scientists, the Hungarian School of Sociology of Law was actually formed. Their views and understanding of law in terms of sociology, penetrated the works of many successors of sociological jurisprudence.

The interwar period was characterized by thorough sociological and legal studies of so-called "national law or legal folk customs".Attempts are being made to theoretically separate "living law" from the positive law."Living law" is governed by the legal traditions of society, and the law laid down in "books" and its results are externally bound by society by the will of the legislator. Thus, "living law" was interpreted as a people's law or customary law, and positive written law was interpreted as compulsory.

However, in fact, the best results of "living law" research have been achieved where the dual aspect of research (ethnography and legal history) has been combined. This position was championed by Barna Horvat (1859-1938). He noted the need to consider law in a dualistic functional connection between nature and law (natural law and positive law). The law is an institutionalized structure of society. In his view, the sociology of law is not a cognition but a method of thinking.

In the 1950s and 1960s, with the beginning of the construction of a socialist society, the emergence of socialist normativism and a politicized approach to understanding the sociology of law were traced [1, p.45]. This approach was first applied in the researches of Ishtvan Dorffi whose 
scientific position was reduced to the following provisions: the legal order is a system of laws that regulates people's lives and is a valid Hungarian national law. Lawmaking should be based on a "living law" that operates in society.

The development of a socialist society required an increasing level of centralization and clear regulation of the law. This led to the formation of a dual content of socialist normativism in the writings of Hungarian scientists.. On the one hand, law and the rule of law were regarded as social phenomena, and on the other, an element of normative reasoning (normativism, positivism) was introduced into the concept of the sociology of law. Based on the conclusions suggested by scientists, the natural consequence of the social situation that creates socialist normativism is the normative nature of the law formed as a result of the political transformation of society. The implementation of the provisions of normative socialism cannot be questioned, and the means of legal regulation are true and dominant [2, p.48].

In the early 1960s, the legal sociological research is aimed at studying the social context of the law. They are associated with the activities of Ishtvan Bibo (1911-1979). His scientific interest was in the study of issues of knowledge of the law by society, the participation of people's assessors in the process of judicial decisions, the assessment of the quality of legal knowledge by society, etc. Based on his own research, Ishtvan Bibo formulated provisions concerning the role of law in the state modernization process [3, p.79].

Since the late 1970s, the sociological jurisprudence of Hungary has seen a confrontation between Soviet legal ideology and Western legal thought. This, of course, influenced the development of the theory and sociology of law in Hungary, and contributed to the emergence of new scientific approaches, in particular, the sociological and legal direction of Kulman Kulchar (1928-2010) and the legal philosophy of Vilmos Peshka (1929-2006).

Sociological and legal direction was to discover from the Marxist positions of the content of the sociology of law as a scientific direction of jurisprudence, analysis of its methodological basis, structure, research of interaction of the sociology of law with related branches of scientific knowledge, ratio of its theoretical and empirical parts, analysis of the connection of sociology of law with the practice of sociology of law socialist construction. Subsequently, Kulman Kulchar sought to reveal the issue of harmonization of Marxism with the legal sociology of Western Europe and the USA.

Vilmos Peshka's legal philosophy envisaged the use of the judgment of the right to interpret the reality in which the right exists and develops. This is necessary in order to find the "level of optimal regulation". Depth of 
this level is a prerequisite for the process of law enforcement and will facilitate the development of social relations.

Professor Peshka was a Marxist, but he did not support communist ideas, and in his early works even criticized socialist normativism. His legal philosophy was based on a rethinking of Marxist positions at their junction with Western (mainly German) legal thought at the time [4]. According to the scientist, Marxism was more oriented to Western society than socialist.

In his work, entitled 'Fundamental problems of modern legal Philosophy' (1972), he opposed the Hungarian legislation with modern Western European law. In this work he formulated the idea that the value and worth of law is determined by his contribution to human's development and realization.

Vilmos Peshka's innovation in Hungarian legal science at the time was that he was in favor of recognizing the legislative function of the judiciary. The scientist argued that the Supreme Court, in its authoritative rulings, adopted in the interpretation of laws and regulations, actually creates the law.

Following the obsessive legal policy of the Soviet authorities, new approaches were perceived as a "breath of clean air", which gave impetus to the growth of research in the socio-legal field, the enrichment of legal thought, the development of identical Hungarian sociology of law. It is noteworthy that Kulchar's proposed institutionalization of legal sociology in Hungary was later reflected in the scientific achievements of scholars of neighboring countries (Romania, Bulgaria, Moldova) [5].

At nowadays, the position of the sociology of law in Hungary has strengthened. Its influence on the development of jurisprudence can be traced in the writings of ChaboVarga. His most famous work is "The Riddle of Law and Legal Thinking". Based on the workings of his predecessors, Chabo Varga noted that under the limited conditions of the communist dictatorship and, despite its ideological orientation, Hungarian sociological and legal science in the second half of the twentieth century. has successfully transformed at least four interrelated areas of legal theory:

1) the initial normative approach to legal theory has changed, and the social view of law has become dominant. This made it possible for Hungarian scholars to use not only a "narrow" understanding of law, but also to analyze its essence through various factors that influence its formation;

2) the introduction into the scientific practice of the historicalcomparative method, which made it universally accepted in the scientific world, opened up new opportunities for research. In the study of subject law, sociological approaches and methods of research are increasingly used;

3) law began to be studied not only as a static element but also as a dynamic component. The effect of law in practice, the analysis of the 
interaction of law with other social regulators, the reaction of society to law, etc. began to be studied;

4) as a general effect of these changes, due to the evolution of the theory of law and the modernization of the sociology of law, scientists have the opportunity to adequately respond to the needs of society in the case of social transformation [6].

Thus, the historical development of Hungarian sociology of law was characterized by a long transition from politically colored science to a sociological and legal understanding of law.

Analyzing the characteristic features of the development of sociological jurisprudence in Hungary, it is worth noting that at the stage of its formation, the sociology of law was part of general sociology. Its roots can be traced in the writings of sociologists and lawyers of the second half of the nineteenth century. In particular, the relationship between society and law has been sociologically investigated in the seminal works of Ahosht Pulski, Bodoga Shomlo, Dyula Pickler, Kulman Kulcharand others. The works of these classics became the basis for the sociological jurisprudence of Hungary, and a number of their scientific theories are used in contemporary Western European sociological and legal thought.

Due to the intellectual efforts of Hungarian scholars, the need to separate the sociology of law into independent science was substantiated with specific methods and approaches to the study of specific legal phenomena.

\section{References}

Rézler Gyula. Bevezetés a szociológiába. Budapest, 1948. 84 p.

Kulcsár K. A jogszociológiaalapjai.. Budapest, 1976. 120 p.

Losonci Á. Azéletmódazidőben, a tárgyakbanésazértékekben. Budapest, 1977, 98 p.

Peschka, V. A jogviszonyelméletalapvetőkérdései . Budapest, 1974;

Kulcsár, K. A jogszociológiaproblémái. Budapest 1982.

Varga, Cs. Lukácss Posthumous Ontologyas Reviewed from a Legal Point of View. Acta Juridica Academiae Scientiarum Hungaricae. № 22. 1980. P. 439-447. 